\title{
HIGH DENSITY FLOW-THROUGH CULTURING OF BRINE SHRIMP ARTEMIA ON INERT FEEDS - PRELIMINARY RESULTS WITH A MODIFIED CULTURE SYSTEM
}

\author{
PATRICE BRISSET, DANNY VERSICHELE, ETIENNE BOSSIJYT, LUC DE RUYCK \\ and PATRJCK SORGELOOS* \\ Artemia Reference Center. State University of Ghent, I. Plateaustrat 22. \\ B-9000 Ghent, Belgium
}

\begin{abstract}
A modified filter system is described for the intensive culruring of Artemia in a cuntinuously renewed medium. Extrapolated to a $1 \mathrm{~m}^{3}$ tank, $25 \mathrm{~kg}$ live weight Arternia could be produced over a culture period of two weeks on a diet of micronized and defatted rice bran using the salt enriched effluent of an abandoned geothermal well as a culture medium.
\end{abstract}

A few years ago the Artemia Reference Center together with the St Croix Marine Station of the University of Texas Marine Science Institute developed a new technique for high density culturing of brine shrimp under flow-through condicions (Tobias et al., 1979). The most important innovation was the interchangeable screen-cylinder with aeration collar that assures efficient drainage of culture water and faecal pellets. Using monospecific algal cultures as combined culture medium and food source, it wis shown at $S t$ Croix that, extrapolated from repeated 100 litre culture trials, up to $25 \mathrm{~kg}$ of Artemia can be produced in a $1 \mathrm{~m}^{3}$ tank within a growing period of only two weeks (Roels er al., 1979).

Since the use of live algae greatly restricts the applicability of this type of intensive culturing of hrine shrimp (Sorgeloos, 1982), we were interested to test flow-through culturing with cheap inert diets that had already proven to be acceptable in the batch culturing of Artemia (Dobbeleir at al., 1980). The availability of sufficient volumes of warm water $\left(5 \mathrm{~m}^{3} \mathrm{~h}^{-1}\right.$ at $29^{\circ} \mathrm{C}$ and $8 \mathrm{ppt}$ salinity) from an abandoned artesian well

- Research Associnte at the National Fund for Scientific Research (Beigium), to whom correspondence should be addressed.

Aquacultural Engineering 0144-8509/82/0001-0115/\$02.75 O Applied Sctence Publishers Lid, England, 1982

Printed in Great Britain 
enabled us to study the technical leasibility of flow-through culturing of Artemia inert feeds. Results reported here were obtained with micronized defatted rice b/ as food source.

Initial testing tevealed that clogging of the filter screen is much more critical w rice bran as food than with live algas; i.e. during the first week when use was made the smallest mesh screens, cylindrical filters appear not to be suited. Filter surfar that are slightly inclined, however, are more efficiently cleaned by the effect of ris! air-bubbles. Taking this into consideration we have developed a new filter system t] is schematically outlined in Fig. 1.

An oblong and funnel shaped frame is assembled with PVC-tubing, elbows and pieces. The four stand-up sides are mounted at an angle of about $9^{\circ}$ with the botto Nylon screen bags (mesh sizes: $130,225,300$ and $400 \mu \mathrm{m}$ ) are sewed to the frame ensure perfect fitting over the frame support. The upper part of the filter, starti from just undemeath the water level, is finished in nylon cloth. For those larvae tf have been foamed off, this smooth nylon surface provides a chance for them to sli back into the culture medium. Furthermore, each filter bag is equipped with a dr: tube ( $2 \mathrm{~cm}$ diameter) mounted in one of its ends under the water level. The fil system, i.e. filter bag fixed on frante, fits exactly into a rectangular aeration col that has been glued to the bottom of tho culture tank. This collar is made of PV tubing, $10 \mathrm{~mm}$ diameter with $1.5 \mathrm{~mm}$ holes at $1 \mathrm{~cm}$ intervals. The air-bubbles rising the outside of filter systems not only prevent clogging of the filter surfaces but at $t$ same time assure sufficient culture aeration and mixing.

The filter system outlined in Fig. 1 was installed in polyethylene tanks ( 1 i 1 $65 \mathrm{~cm}$ ) containing a 500 litre culture medium. Well water was pumped into a consta head cylinder that also acted as sand filter. Flow rates to the individual culture tan were adjusted so as to assure acceptable removal of faecal pellets. Working with a lart density of 10000 litre $^{-1}$ culture water, retention times were kept at $3 \mathrm{~h}$ during $\mathrm{t}$ first week and were then progressively lawered to a minimum of $\mathrm{I} \mathrm{h}$ from day 100 wards. Once every day filters were lilted out of the culture tanks and cleaned. On da 3,6 and 9 filter bags were changed for in larger mesh size. Every $5 \mathrm{~min}$ microniz rice bran suspension ( $20 \mathrm{~g}$ litre ${ }^{-1} \mathrm{Na}\left({ }^{\prime} / \mathrm{h} / \mathrm{H}_{\mathrm{o}}\right.$ ) was pumped into the culture tanks usi the automatic distribution systen dewulliud in Bossuyt and Sorgeloos (1980). Feedi rates were adjusted so as to mulılulı the culture medium transparency, measust inside the filter system with a mudilled Secchidisc (Bossuyt and Sorgeloos, 1980 within the range $15-20 \mathrm{~cm}$ durily the flryt culturing week and $20-25 \mathrm{~cm}$ during $\mathrm{tl}$ second week (Sorgeloos et al., 1982). Water temperature in the culture tan fluctuated between 26 and $27^{\circ} \mathrm{C}$.

The first culture tests with the llew set-up revealed that the rectangular/funn shaped filter bag-system is vory woll suited to flow-through culturing of Artemia , rice bran. Pioduction results with Great Salt Lake (Utah, USA) Artemia, howevt were low due to proliferation of lliamentous bacteria and peritrichous ciliates in il low salinity waters. Best havasis at the end of the two-week culturing period on amounted to an extrapolated \& $\mathrm{kL}_{\mathrm{m}}^{-3}$ (Brisset, 1981). 


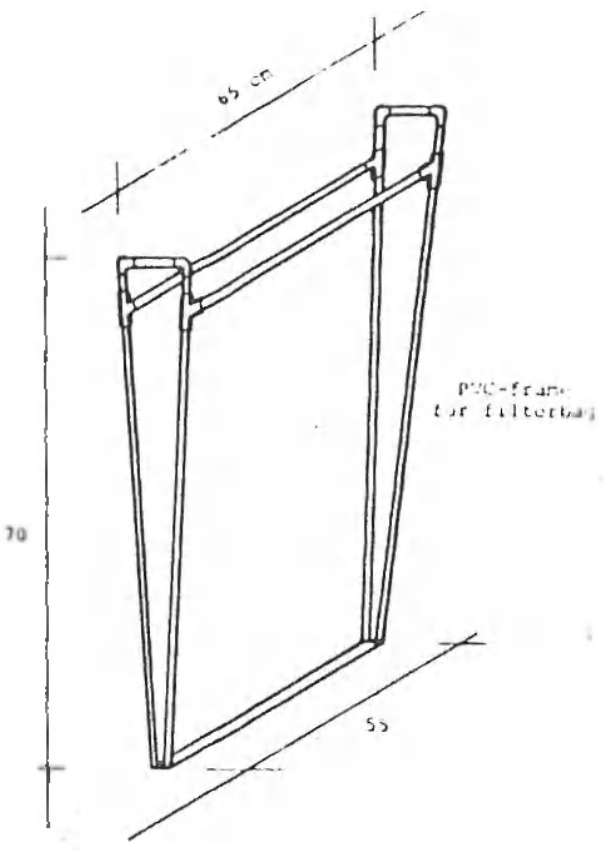

S ILE

$\checkmark$ IEW

LATERAL

VIER

$\frac{15}{T-T}$
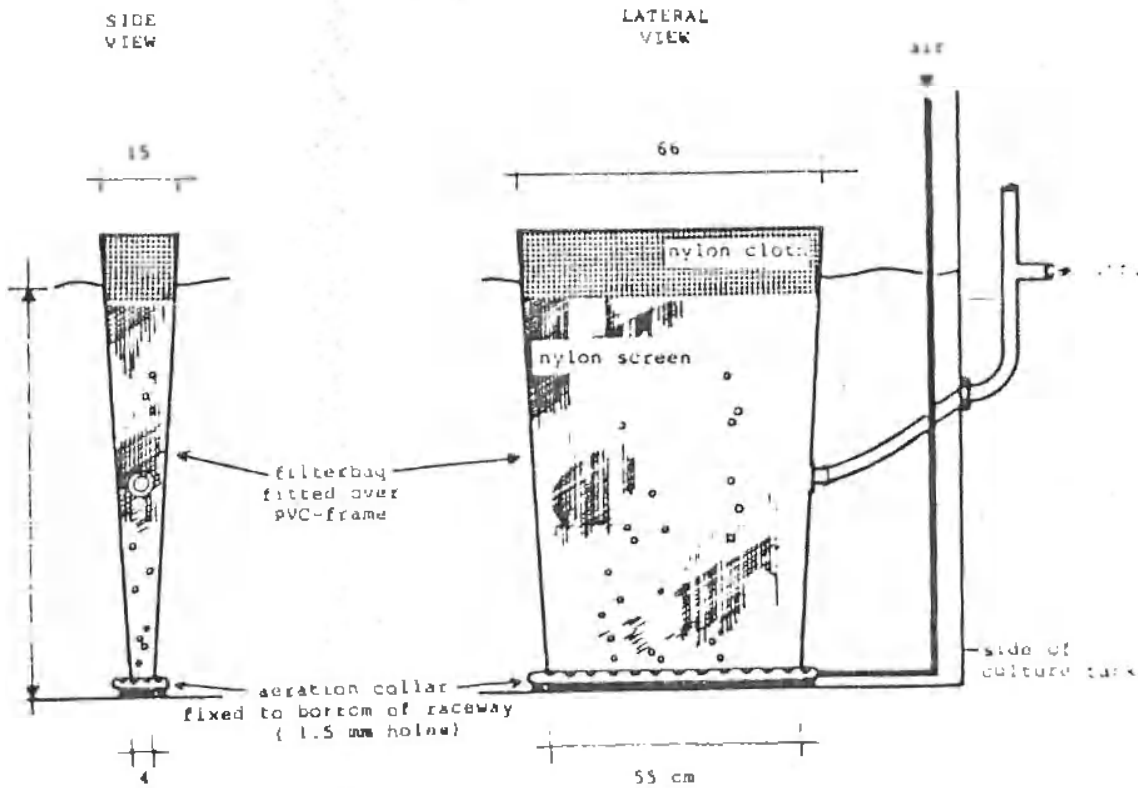

Fig. 1. Schematic diagrams of new filter-systerns. 
In order to verify the effect of low salinity, a last series of experiments was conducted in Turnhout (Belgium) with salt entiched well water. Salinity levels in the culture tanks were maintained at about 35 prit by continuous addition of saturated NaCl-brine from a Sterling brinomat (Spotte, 1970; Sorgeloos et al., 1982) into the inflowing well water. Artemia cultures were not contaminated any more with hamful floccules and high production yields wero achieved: i.e. after two culturing weeks in a 500 litre tank $13 \mathrm{~kg}$ live weight pre-adults were harvested for a total consumption of $8 \mathrm{~kg}$ micronized rice bran and $55 \mathrm{~m}^{3}$ culture water. Extrapolated to a $1 \mathrm{~m}^{3}$ tank this means a production capacity of $25 \mathrm{~kg}$ Artemia, which is comparable to the yields obtained on St Croix with live algae.

Although the production results repurted here are about four times higher than the best figures reported for batch culturing of Artemia with the same inert feed (Bossuyt and Sorgeloos, 1981), they should be condidered as preliminary. It is indeed very likely that further $R \& D$ with regard to maximill larval densities, minimal food demands, optinal flow rates, etc., will result in locstused production capacities. Flow-through culturing of Artemia on inert feeds could furthermore be intensified by partial recycling of culture effluents.

In conclusion, we are convinced that, flluvlded cheap sources of suitable feed and culture water are available, industrial pronductlon of Artemia will become attractive for specific uses of this high quality animal pilutuln.

\section{ACKNOWIRDGEMENTS}

The existence of the geothermal well in Tumhout was brought to our attention by Mr R. Foblets (Brasschat). Permlsgiorn to run the culture experiments with the well water was obtained from the city of Turnhout, who furthermore provided technical facilities during construction and apuation of the experimental facility. Micronized deratted rice bran was made avallutala for this research by NV Nieuwe Molens Brugge en Gent. Partial financing for thin xtully has been received from the Belgian Ministry of the Flemish Region.

\section{WHERENCES}

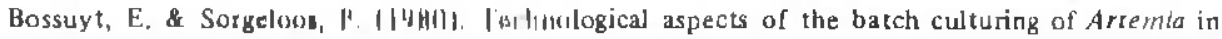

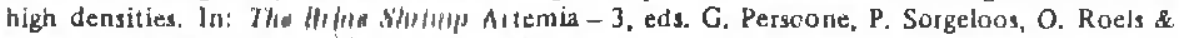
E. Jaspers, Universu I'send, Wrllore:11, IJ1 IJ3-52.

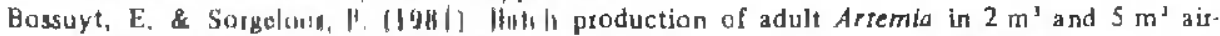
weter-lift operaled lutultibs Prillit ('untributed papers (poster session), World Conference on Aquaculture, Ventice, lialy, 31 13 September. 1981, poster No. 17

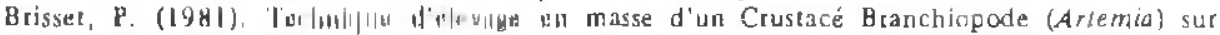

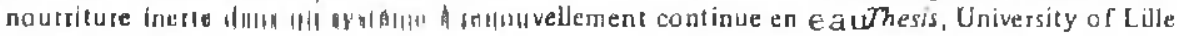
I, France. 85 ון. 
Dobbeleir. J., Adam, N., Bossuyt, E., Bruggeman, E. \& Sorgeloos, P. (1980). New aspects of the use of inert diets for high density cultuting of brine shrimp. In: The Brine Shrimp Arternia - 3, eds. G. Persoone, P. Sorgeioos, O. Roels \& E. Jaspers, Universa Press, Wetteren, pp. 165-74.

Roels, O. A., Sharfstcin, B. A. \& Tobias, W. 1. (1979). Artifictal Upwelling: Progress Report 1978-79. Culliwation of the Brine Shrimp Artemin. Final report for the work supported by NOAA Sea Grant Project No. NA-79-AA-D.00039. 256 pp.

Sorgeloos, P. (1982). Live animal food for larval rearing in aquaculture: the brine shrimp Artemia. Review paper presented at the Wnrld Conference on Aquaculrure, Venice, Italy. 21-25 September. 1981, (proccedings in press).

Sorgeloos, P., Bossuyt, E,Lavens E Léger, Ph., Varhaccke, P. \& Versichele, D. (1982). The usc of the brine shrimp Artema in crustacean hatcherics and nurseries. In: Martculture, ed. J. P. M-Vey, CRC Handbook in Marine Science, in press.

Sp S. (1970). Fish and invertehrate culture. Water Management In Closed Systems. WilcyInterscience, New York, 145 pp.

Tobias, W. J., Sorgeloos, P., Bossuyt, E. \& Roels, O. A. (1979). The technical feasibility of massculturing Arfemia salina in the St. Croix 'artificial upwelling' mariculture system. In: Proc, 10th Ann. Meeting World Mortculture Society, ed. J. W. A vault, Jr, Louisiana State University, Baton Rouge, pp. 203-14. 